\title{
NKX3-1 Gene
}

National Cancer Institute

\section{Source}

National Cancer Institute. NKX3-1 Gene. NCI Thesaurus. Code C24631.

This gene plays a role in transcriptional regulation and is a putative prostate tumor suppressor. 